\title{
Morphological and Anatomical Features of the Flowers and Fruits during the Development of Chamissoa altissima (Jacq.) Kunth (Amaranthaceae)
}

\author{
Sayuri de Oliveira Oyama, Luiz Antonio de Souza*, Júnior Cesar Muneratto and Adriana \\ Lenita Meyer Albiero \\ Departamento de Biologia; Universidade Estadual de Maringá; Av. Colombo, 5790; 87020-900; Maringá - PR - \\ Brasil
}

\begin{abstract}
The morphology and structure of the flowers and fruits of Chamissoa altissima (Jacq.) Kunth during the development were analyzed. The plant material was fixed in FAA 50, embedded in historesin and sectioned according to standard techniques. The flowers presented tepals with betalain and homogeneous mesophyll; receptacular nectary; anthers with epidermis, endothecium, one middle layer, and uninucleate tapetum; and monocarpelar ovary with homogeneous mesophyll. The fruit was a circumscissile capsule, presented the same number of cellular layers that the ovary, and possessed subendocarpic sclerenchyma. The seed was bitegmic, exotestal and perispermic.
\end{abstract}

Key words: Perianth, stamen, gynoecium, pericarp, seed

\section{INTRODUCTION}

Lianas or vines are vascular plants that are rooted in the ground and maintain their stems in a more or less erect position by making the use of the other objects for support. This habit of the growth has the advantage of enabling the plant to get better light with a maximum economy of supporting tissues (Daubenmire, 1974). They are of minor economic importance in the forestry, but have great ecological relevance in the forests, supplying the foods for the animals, aiding in the stabilization of trees and competing for light and nutrition or causing the mechanical damages.

The morphological and anatomical studies of Brazilian lianas usually have restricted to the stem. Reports about the reproductive organ investigations are scarce. In the forest remnants of the Northwest region of Paraná (less than $1 \%$ of native vegetation) a diversity of liana species occurs, belonging to different families. Chamissoa altissima (Jacq.) Kunth is abundant in these forest remnants in which the reproductive organs still have not been investigated.

Amaranthaceae that includes Chenopodiaceae, possesses determinate inflorescences (terminal and axillary), with flowers bisexual or, less commonly, unisexual, actinomorphic and monochlamydeous (Judd et al., 2002; Souza and Lorenzi, 2005). Spjut (1994) reported cypsela, pyxidium and utricle fruits for the family. Judd et al. (2002) distinguished Amaranthaceae fruits as an achene, utricle, or a circumscissile capsule (pyxis), usually associated with persistent, fleshy to dry, perianth

"Author for correspondence: lasouza@uem.br 
and/or bractlets. Souza and Lorenzi (2005) reported for Amaranthaceae circumscissile capsule, achene and more rarely berry or drupe. Chamissoa H. B. K. presents spikes or panicles with flowers usually bisexual, fruits with transversal dehiscence, and arillate seeds (Smith and Downs, 1972). Barroso et al. (1999) considered Chamissoa consisting of circumscissile capsule often associated with persistent bracts, bractlets and perigon, and endosperm.

The flower, fruit and seed anatomy of Amaranthaceae/Chenopodiaceae was scarce in the literature. Singh (1964) presented brief description of the family. Corner (1976) reported Chamissoa seeds with funicular aril. Pal et al. (1990) studied the development and the structure of Amaranthus hypochaondriacus L. seeds. Prego et al. (1998) described the seed structure of Chenopodium quinoa Willd. Ronse-Decraeme et al. (1999) analyzed the floral development of Pleuropetalum darwinii Hook. Costea et al. (2001) investigated the pericarp structure in Amaranthus L. species. Shepherd et al. (2005) examined the variation in the morphology, anatomy and histochemistry of Salicornioideae (Chenopodiaceae) fruits and seeds. Biological studies of lianas, mainly related to the reproductive organs, have ecological importance; they are useful in the control investigations of these species. In view of this, the main purpose of this work was to present the available information on the morphology and anatomy of Chamissoa altissima flower and fruit during the development.

\section{MATERIALS AND METHODS}

The flowers and fruits of different developmental stages of two specimens of Chamissoa altissima were collected at the forest remnant of Maringá, Paraná, Brazil. Voucher materials were deposited at the UEM Herbarium, collection 11731 HUEM. The analysis of the flowers and fruits was done using freshly-collected material or material fixed in FAA 50 and FPA 50, following the protocol of Johansen (1940). The fixed material was embedded in historesin and sectioned (cross- and longitudinal sections) in a rotation microtome, according to techniques of Feder and O'Brian (1968)). The sections were stained in toluidine blue (O'Brien et al., 1965). Developing fruits were analyzed in freehand sections stained in astra blue and safranin (Kraus and Arduin, 1997). Specific microchemical tests were done for lipid substances (Sudan III) (Johansen, 1940), mucilage (methylene blue) (Costa, 1972), betalain (ammonia vapor) (Johansen, 1940), starch (iodine-potassium iodide test) and lignin (phloroglucin test) (Berlyn and Miksche, 1976).

Micromorphological analysis (Bozzola and Russel, 1992) was done with fixed material. After washing in $0.1 \mathrm{M}$ sodium cacodylate buffer, the samples were dehydrated in a graded acetone series, critical point dried with $\mathrm{CO}_{2}$, and then mounted on aluminum stubbs, gold coated, and subsequently examined using scanning electron microscopy (Shimadzu SS-550 Superscan). Illustrations were prepared using a stereomicroscope Willd M3Z equipped with a reflex camera. Photographs were taken with the microscope (Olympus BX50, digital camera Canon Power Shot A95), and subsequently prepared using the software Zoom Browser EX 4.6. All the samples were prepared on the same micrometric scale.

\section{RESULTS}

\section{Flower}

The flowers were bisexual and occurred in panicle, each flower associated with three bracts (Fig. 1A). Each flower presented five or six green tepals, five or six stamens, and a gynoecium with one pistil (Figs. 1B, C). The pistil consisted of globose ovary, style, bipartite/tripartite stigma (Figs. 1B, $\mathrm{C})$, and only one ovule with basal placentation.

The tepals (Figs. 2A, C) presented uniseriate epidermis with cuticle flange, and periclinal thickwalled cells in the abaxial face and thin-walled cells in the adaxial face. There was a hypodermis with thick-walled cells in the adaxial surface (Fig. 2C). The parenchymatic mesophyll (Fig. 2C) was homogeneous and chlorophyllaceous, with one to four cell layers. In the tepal margin and apex, there was no mesophyll. The vascularization was made by the largest vein (midrib) from which smaller veins branched. In the midrib, there was a single collateral bundle (Fig. 2C). The vascular bundles showed fibers in the xylem face. 


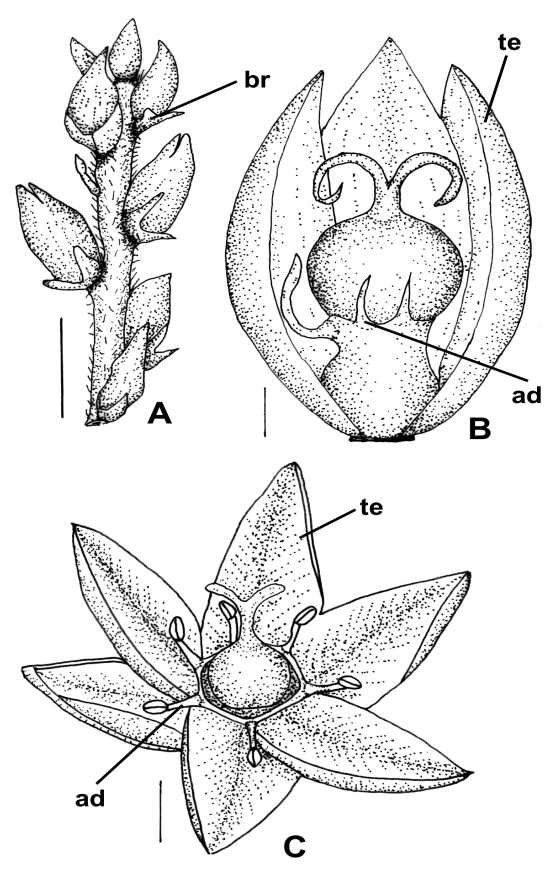

Figure 1 - Morphology of the Chamissoa altissima flower. A - Inflorescence branch with flowers. $\mathrm{B}$ and $\mathrm{C}-$ Flowers in anthesis. $(\mathrm{ad}=$ androecium; $\mathrm{br}=$ bract; te $=$ tepals $)$ Bars $=3.7 \mathrm{~cm}$, $0.6 \mathrm{~cm}, 0.8 \mathrm{~cm}$, respectively.

The nectary (Fig. 2A) occurred in the receptacle and consisted of two regions, one was convex, globular and close to the base of the ovary and the other was laminar and remained around the ovary base. The globular portion (Fig. 2B) possessed epidermis with modified stomata and nectariferous tissue with polyhedral cells and relatively richer in protoplasma. The laminar portion (Fig. 2B) presented epidermis with slightly elongated and papillose cells and two to four layers of parenchymatous cells. The vascularization of the nectary consisted only of phloem. The anther was tetrasporangiate. The immature anther wall (Fig. 2D) was constituted by a uniseriate epidermis with tabular cells, endothecium, one middle layer and secretory tapetum with uninucleate cells. The filament presented papillose epidermis, parenchyma, and one collateral vascular bundle. The ovary wall (Figs. 2A, 4A) was composed of uniseriate outer and inner epidermis and parenchymatous mesophyll with three or four cellular layers. The vascularization was done by two collateral bundles. The style (Fig. 2F) had lenticular shape and presented a single epidermis, parenchyma, two collateral vascular bundles and central transmitting tissue. The style was hollow in the distal portion and presented a solid nature in the base. The stigma (Fig. 2E) possessed secretory epidermis with unicellular hairs.

The ovule (Figs. 5A,B) was campylotropous, bitegmic, crassinucellate and had a long funiculus. Only the inner integument took part in the formation of the micropyle (Fig. 5B). The outer integument (Fig. 5B) was biseriate with the outer layer composed of radially elongated cells mainly close to the micropyle. The inner integument (Fig. 5B) was also bi-layered, but a third layer in the apex could be present. The nucellus was parenchymatous. It was formed aril in the ovule of funicular origin, still in pre-anthesis stage. 


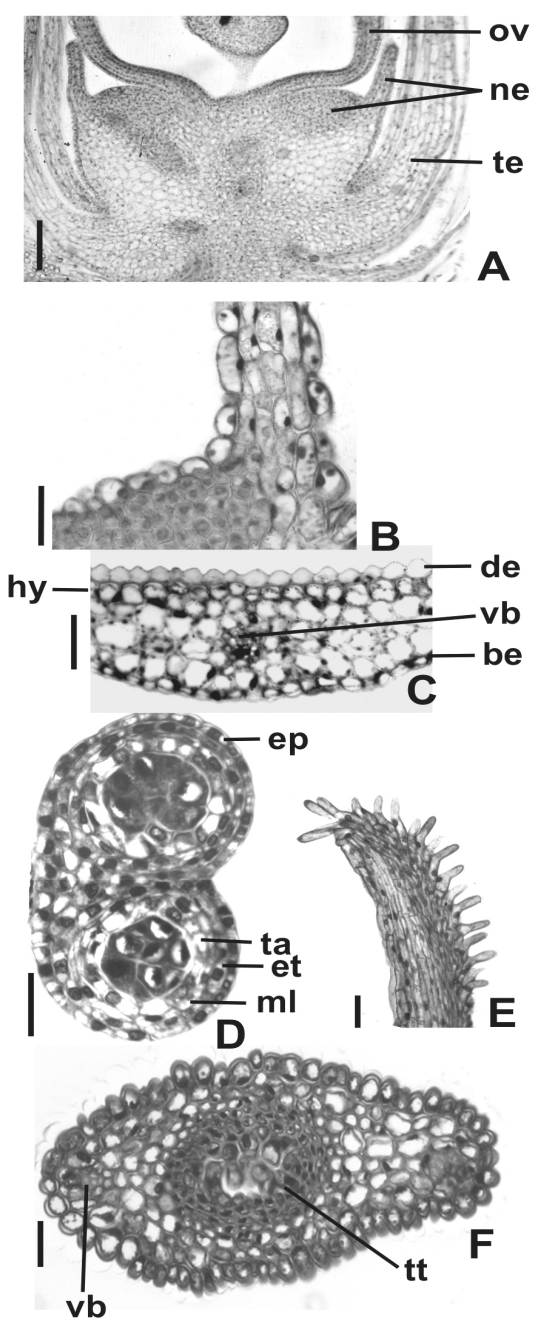

Figure 2 - Flower structure of Chamissoa altissima. A - Flower in longitudinal section. B - Detail of the globular and laminar portions of the nectary. C - Detail of the tepal in crosssection. D - Anther in cross-section. E - Stigma in longitudinal section. F - Style in cross-section. (be = abaxial epidermis; de = adaxial epidermis; ep = epidermis; et = endothecium; hy = hypodermis; $\mathrm{ml}=$ middle layer; $\mathrm{ne}=$ nectary; ov = ovary; $\mathrm{st}=$ stamen; $\mathrm{ta}=$ tapetum; te = tepal; $\mathrm{tt}=$ transmitting tissue; $\mathrm{vb}=$ vascular bundle) $\mathrm{Bars}=$ $50 \mu \mathrm{m}(\mathrm{A}, \mathrm{B}, \mathrm{C}, \mathrm{D}, \mathrm{F}), 20 \mu \mathrm{m}(\mathrm{E})$.

\section{Fruit and seed}

The fruit was usually associated with persistent tepals and style. In the mature fruit, the tepals were red due to the betalain presence. The fruit was a circumscissile capsule dehiscing by a lid (Fig. 3). During the pericarp differentiation, there was reduced structural alteration and partial sclerification of the mesocarp (Fig. 4A, B) and the formation of the abscission tissue (Fig. 4C) was observed.
The mature pericarp (Fig. 4B) presented glabrous epidermal epicarp with tangentially elongated cells. The mesocarp consisted of parenchyma and sclerenchyma. The sclerenchymatic mesocarp was composed of one to three layers of sclereids which presented thick and sinuous cell walls with simple pits. The endocarp was represented by the inner epidermis and consisted of large cells with thinwalled which could break up easily (Fig. 4B). The abscission tissue was loose and it was constituted of thin-walled cells. 


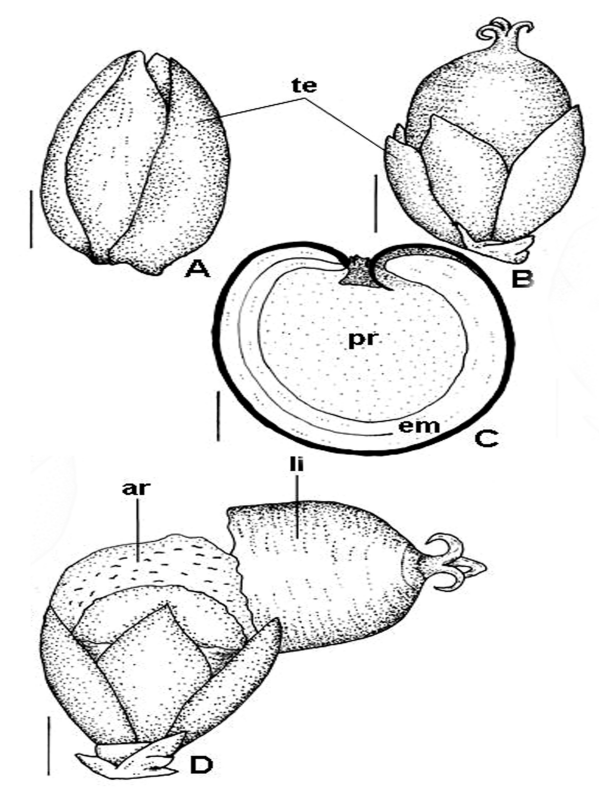

Figure 3 - Fruit and seed morphology of Chamissoa altissima. A, B - Young fruits. C - Seed sectioned longitudinally. $\mathrm{D}$ - Mature fruit. (ar = aril; em = embryo; li = lid; pr = perisperm; te $=$ tepal). Bars $=0.7 \mathrm{~mm}(\mathrm{~A}), 1.2 \mathrm{~mm}(\mathrm{~B}, \mathrm{D}), 0.5 \mathrm{~mm}(\mathrm{C})$.

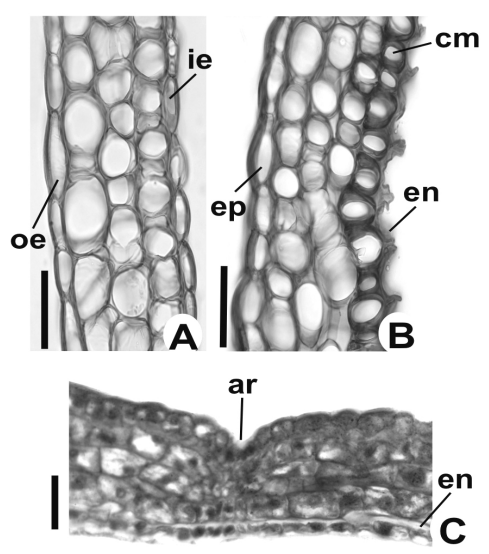

Figure 4 - Pericarp in developing of Chamissoa altissima. A - Ovary in cross-section. B - Mature pericarp in cross-section. $\mathrm{C}$ - Young pericarp in longitudinal section. ( $\mathrm{ar}=$ abscission region; $\mathrm{cm}=$ sclerenchymatic mesocarp; $\mathrm{en}=$ endocarp; ep = epicarp; ie = inner epidermis; oe $=$ outer epidermis) Bars $=50 \mu \mathrm{m}$.

The integuments were not multiplicative. The exotesta cells (Fig. 5C) underwent shortly radially elongation and the inner cell layer could undergo periclinal division in certain regions of the young seed becoming biseriate. In the outer surface of the exotesta thick cuticular layer was deposited. In the biseriate tegmen (Fig. 5C), the inner layer presented cuboid cells and the outer layer showed small tabular cells which became crushed.
Endosperm was nuclear. The funicular aril (Fig. 5D) developed as loops of the elongated cells with large vacuoles and nuclei.

The mature seed (Figs. 3C, D) was lenticular, black, and it was involved completely by white, fleshy and wrinkled surface aril. It was bitegmic and exotestal. The exotesta was composed of short elongated sclereids with lignified reticulate thickwalled cells. The exotesta was covered by the 
cuticle and thick striate cuticular layer. The testa still consisted of one to three layers of parenchymatous cells (Fig. 5E). The tegmen (Fig. $5 \mathrm{E})$ possessed one cellular layer, occurring two strata eventually. The perisperm (Fig. 3C) showed epidermis with cuticle and parenchyma with content poorly oily and calcium oxalate crystals. The embryo (Fig. 3C) was curved with long hypocotyl-radicle axis and two cotyledons of different dimensions.
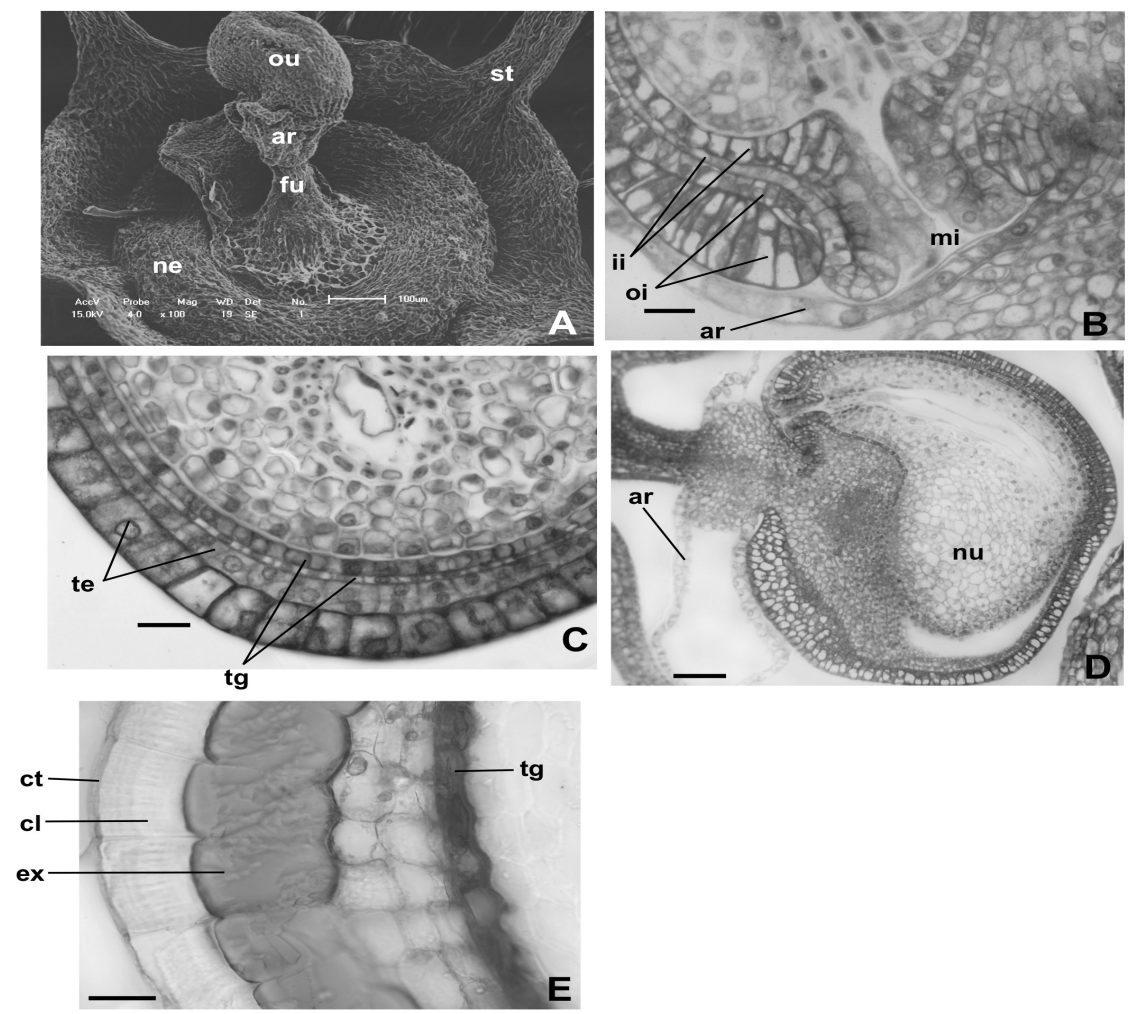

Figure 5 - Ovule and seed structure of Chamissoa altissima. A - Scanning electron micrographs showing ovule and nectary. B - Detail of micropylar region of the ovule in longitudinal section. C - Detail of chalazal region of the young seed in longitudinal section. D Young seed in longitudinal section. E - Mature seed integuments in cross-section. ( $\mathrm{ar}=$ aril; $\mathrm{cl}=$ cuticular layer; $\mathrm{ct}=$ cuticle ; ex = exotesta; $\mathrm{fu}=$ funiculus; $\mathrm{ii}=$ inner integument; $\mathrm{mi}=$ micropyle; $\mathrm{nu}=$ nucellus; ne = nectary; oi = outer integument; ou = ovule; $\mathrm{st}=$ stamen; te $=$ testa; $\operatorname{tg}=$ tegmen $)$ Bars $=20 \mu \mathrm{m}(\mathrm{B}, \mathrm{C}, \mathrm{E}), 50 \mu \mathrm{m}(\mathrm{E})$.

\section{DISCUSSION}

The persistent perianth or perigone on the fruit can develop different functions and/or undergo structural modifications. In the literature, there are several examples in which the perianth/perigone may serve as a protective organ as well as a means of seed dispersal at fruit maturity, as for instance in Asteraceae, Boraginanaceae, Verbenaceae and Nyctaginaceae (Roth, 1977; Souza, 2006, 2008). In $C$. altissima, the tepals initially acted as protective and photosynthetic functions and after acquiring the red color it should act in the seed dispersal. In fact, Mikich and Silva (2001) considered this species as zoochoric in a forest remnant of the Paraná, Brazil.

The $C$. altissima floral nectary developed on the receptacle could be classified as toral nectary, in agreement with Fahn (1990). According to Fahn (1990), when the secretory cells are parenchymatous, nectar is secreted into the intercellular spaces from which it is exuded via modified stomata. The $C$. altissima nectary seemed to have this secretion and exudation type, for presenting secretory parenchyma and stomata.

The immature anther wall of $C$. altissima just presented a middle layer. In agreement with the anther wall formation and definitions of the types 
of walls (Davis, 1966), the anther of this species could belong to the Monocotyledonous type, common in Caryophyllanae (Dahlgren, 1991). In the Monocotyledonous type, periclinal divisions are suppressed in the outer secondary parietal layer which develops directly into endothecium, while the inner layer forms the middle layer and the tapetum. However, the definitive inclusion of the C. altissima anther in the Monocotyledonous type needs ontogenetic study of the anther wall.

The differentiation of the ovary wall in the pericarp of $C$. altissima didn't involve increase of cellular layers. In this the cell divisions ceased very early during the fruit development, before fertilization, unlike drupes, legumes, follicles and capsules that formed adaxial (ventral) meristem after the pollinization (Roth, 1977; Souza et al., 2004; Souza, 2006; Souza et al., 2008). The fruit differentiation of $C$. altissima consisted mainly in cell enlargement of the pericarp, thickening of cell walls of subendocarpic mesocarp, and formation of the abscission zone.

The mature pericarp of $C$. altissima presented reduced number of cellular layers, 6-7 layered structure. The Amaranthus species pericarp showed 2-4 layered structure, consisting of 1layered epicarp, 1-2 layered mesocarp and 1layered endocarp (Costea et al., 2001). There is not sclerenchyma in the Amaranthus species mesocarp as in $C$. altissima; in the Amaranthus species occurs the thickening of walls in endocarp cells.

In the literature, the fruit registered for Chamissoa H. B. K. is classified as pyxidium (or pyxis) or circumscissile capsule (Smith and Downs, 1972; Barroso et al., 1999). In fact, C. altissima presented this fruit type that dehisces by a single transverse rift. The $C$. altissima fruit was structurally similar to the Plantago L. one (Souza, 2006) which showed pericarp with few cell layers, sclerenchymatous subendocarpic mesocarp and circumscissile dehiscence. The disappearance of seed coat cells may occur through their absorption by the growing endosperm, serving as nutrients, or by being crushed and obliterated through the growth of the endosperm and embryo, or through desiccation when thin-walled (Werker, 1997). In Amaranthaceae/Chenopodiaceae, the integuments are reduced generally to the exotesta and the endotegmen, but with three cuticular layers (Corner, 1976). In Amaranthus hypochondriacus, the cells of the inner integument and the inner epidermis of the outer integument finally degenerate in a mature seed (Pal et al., 1990). In
C. altissima, the testa and the endotegmen remained in the seed coat, degenerating only the outer layer of the inner integument.

The white aril of $C$. altissima was funicular and started its formation in the pre-anthesis ovule. It occurs typically in the genus (Corner, 1976). Werker (1997) reported that the aril, usually colored, was attractive to the group of animals, which acted as dispersal agents, like orange for ornitochory and white or yellow for myrmecochory. According to Kapil et al. (1980) the aril-like appendages are the types of accessory seed outgrowths. These most impressed the botanists and, in fact, brought about the greatest differences of opinion by their heterogenic shapes, sizes and ways of development. The authors considered that the one group of arils which perhaps could not be accounted for were the true funicular arils, which originated independently from the seed coat, and should therefore be treated as separate category.

Chamissoa altissima presented the general pattern of Amaranthaceae seed as reported by Singh (1964) and Corner (1976) as bitegmic and exotestal seed, persistent inner epidermis in the tegmen, perisperm and curved embryo. However, all the embryos of Amaranthaceae/Chenopodiaceae are not curved. Shepherd et al. (2005) reported that the peripheral embryos of the Salicornioideae (Chenopodiaceae) could further characterized as bent, curved and straight.

\section{RESUMO}

Chamissoa altissima (Jacq.) Kunth ocorre em remanescentes florestais de Maringá, Paraná, Brasil e se destaca por seus frutos zoocóricos envolvidos por sépalas vermelhas. As flores e frutos em diferentes fases de desenvolvimento são descritos estruturalmente. O material botânico foi fixado em FAA 50, emblocado em historresina e secionado conforme técnicas usuais. As flores apresentam sépalas com betalaína e mesofilo homogêneo; nectário receptacular; anteras com epiderme, endotécio, uma camada média e tapete uninucleado; e ovário monocarpelar com mesofilo homogêneo. O fruto é uma cápsula circuncisa, apresenta o mesmo número de camadas celulares que o ovário, e possui esclerênquima subendocárpico. A semente é bitegumentada, exotestal e perispérmica. 


\section{ACKNOWLEDGMENTS}

We thank CNPq (Conselho Nacional de Desenvolvimento Científico e Tecnológico, Brasil) for supporting this work (PIBIC Grant to S. O. Oyama and Research grant to L. A. Souza). We also thank Dr. O. A. Guimarães, UFPR, Brazil, for the species identification.

\section{REFERENCES}

Barroso, G. M.; Marin, M. P.; Peixoto, A. L. and Ichaso, C. L. F. (1999), Frutos e sementes (morfologia aplicada à sistemática de dicotiledôneas). Editora Universidade Federal de Viçosa, Viçosa.

Berlyn, P. G. and Miksche, J. P. (1976), Botanical microtechnique and cytochemistry. The Iowa State University Press, Ames.

Bozzola, J. J. and Russell, L. D. (1992), Electron microscopy. Jones and Bartlett Publishers, Boston.

Corner, E. J. H. (1976), The seeds of dicotyledons. Cambridge University Press, Cambridge.

Costa, A. F. (1972), Farmacognosia (farmacognosia experimental). Fundação Calouste Gulbenkian, Lisboa.

Costea, M.; Waines, G. and Sanders, A. (2001), Structure of the pericarp in some Amaranthus L. (Amaranthaceae) species and its taxonomic significance. Aliso, 20, 51-60.

Dahlgren, G. (1991), Steps toward a natural system of the dicotyledons: embryological characters. Aliso, 13, 107-165.

Daubenmire, R. F. (1974), Plants and environment: a textbook of plant autecology. John Wiley and Sons, New York.

Davis, G. L. (1966), Systematic embryology of the angiosperms. John Wiley and Sons, New York.

Fahn, A. (1990), Plant anatomy. Pergamon Press, Oxford.

Feder, N. and O'Brian, T. P. (1968), Plant microtechnique: some principles and new methods. Amer. J. Bot., 55, 123-142.

Johansen, D. A. (1940), Plant microtechnique. McGraw-Hill Book, New York.

Judd, W. S.; Campbell, C. S.; Kellogg, E. A.; Stevens, P. F. and Donoghue, M. J. (2002), Plant systematics: a phylogenetic approach. Sinauer Associates, Sunderland.

Kapil, R. N.; Bor, J. and Bouman, F. (1980), Seed appendages in angiosperms. Bot. Jahrb. Syst., 101, 555-573.

Kraus, J. E. and Arduin, M. (1997), Manual básico de métodos em morfologia vegetal. Editora Universidade Rural, Seropédica.
Mikich, S. B. and Silva, S. M. (2001), Composição florística e fenologia das espécies zoocóricas de remanescentes de floresta estacional semidecidual no centro-oeste do Paraná, Brasil. Act. Bot. Bras., 15, 89-113.

O'Brien, T. P.; Feder, N. and McCully, M. E. (1965), Polycromatic staining of plant cell walls by toluidine blue O. Protoplasma, 59, 368-373.

Pal, A.; Singh, R. P. and Pal, M. (1990), Development and structure of seeds in Amaranthus hypochaondriacus L. and its wild progenitor $A$. hybridus L. Phytomorphology, 40, 145-150.

Prego, I.; Maldonado, S. and Otegui, M. (1998), Seed structure and localization of reserves in Chenopodium quinoa. Ann. Bot., 82, 481-488.

Ronse-Decraene, L. P.; Volgin, S. A. and Smets, E. F. (1999), The floral development of Pleuropetalum darwinii, an anomalous member of Amaranthaceae. Flora, 194, 189-199.

Roth, I. (1977), Fruits of angiosperms. In-Encyclopedia of plant anatomy, ed. K. Linsbauer. Gebrüder Borntraeger, Berlyn, pp. 21-131

Shepherd, K. A.; Macfarlane, T. D. and Colmer, T. D. (2005), Morphology, anatomy and histochemistry of Salicornioideae (Chenopodiaceae) fruits and seeds. Ann. Bot., 95, 917-933.

Singh, B. (1964), Development and structure of angiosperms seed - I. Review of the Indian Work. Bull. Nat. Bot. Gard., 89, 1-115.

Smith, L. B. and Downs, R. J. (1972), Amarantáceas. In-Flora ilustrada catarinense, ed. R. Reitz. Herbário Barbosa Rodrigues, Itajaí, pp. 11-18

Souza, L. A. (2006), Fruto. In-Anatomia do fruto e da semente, org.. L. A. Souza. Editora Universidade Estadual de Ponta Grossa, Ponta Grossa, pp. 15-29

Souza, L. A. (2008), Morphology and anatomy of the Cordia trichotoma (Vell.) Arrab. ex I. M. Johnst diaspore (Boraginaceae). Braz. Arch. Biol. Tech., 51, 761-768.

Souza, L. A.; Moscheta, I. S.; Mourão, K. S. M. and Rosa, S. M. (2004), Morphology and anatomy of the flower and anthesis of Metrodorea nigra St. Hill. (Rutaceae). Braz. Arch. Biol. Tech., 47, 107-112.

Souza, L. A.; Rosa, S. M. and Moscheta, I. S. (2008), Anatomy of the developing fruit of Metrodorea nigra A. St.-Hil. (Rutaceae). Braz. Arch. Biol. Tech., 51, 1171-1179.

Souza, V. C. and Lorenzi, H. (2005), Botânica sistemática: guia ilustrado para identificação das famílias de angiospermas da flora brasileira, baseado em APG II. Instituto Plantarum de Estudos da Flora, Nova Odessa.

Spjut, R. W. (1994), A systematic treatment of fruit types. Mem. New York Bot. Gard., 70, 1-181.

Werker, E. (1997), Seed anatomy. Gebrüder Boerntraeger, Berlin.

Received: May 05, 2009; Revised: July 03, 2009; Accepted: June 06, 2010. 